\title{
Refractory Chronic Pouchitis and Autoimmune Hemolytic Anemia Successfully Treated with Vedolizumab
}

\author{
Diana Martins Paula Ministro Américo Silva \\ Gastroenterology Department, Centro Hospitalar Tondela-Viseu, Viseu, Portugal
}

\section{Keywords}

Hemolytic anemia · Pouchitis - Ulcerative colitis ·

Vedolizumab

\section{Pouchitis Crónica Refratária e Anemia Hemolítica Auto-Imune Tratadas com Sucesso com Vedolizumab}

\section{Palavras Chave}

Anemia hemolitica · Pouchitis · Colite ulcerosa ·

Vedolizumab

Pouchitis is the most common adverse event among patients with ulcerative colitis (UC) who underwent restorative proctocolectomy with ileal pouch-anal anastomosis. Although initial acute episodes typically respond to antibiotics, patients may become antibiotic dependent or develop refractory disease [1]. Immunosuppressants, anti-TNFs, topical therapy, and surgery are therapeutic options when refractoriness is established but final decision is still based on a case-by-case basis [2]. Recently, few case reports of successful use of Vedolizumab and Ustekinumab in refractory pouchitis have been published $[3,4]$. Autoimmune hemolytic anemia (AIHA) is a rare extraintestinal manifestation of UC, usually responding to proctocolectomy [5], with no previous reports of AIHA

\section{KARGER}

E-Mail karger@karger.com www.karger.com/pjg
(C) 2018 Sociedade Portuguesa de Gastrenterologia

Published by S. Karger AG, Basel

Karger

Open access

This article is licensed under the Creative Commons AttributionNonCommercial-NoDerivatives 4.0 International License (CC BYNC-ND) (http://www.karger.com/Services/OpenAccessLicense) Usage and distribution for commercial purposes as well as any distribution of modified material requires written permission. starting after surgery. We report the singular case of a patient with chronic pouchitis (CP) and AIHA, refractory to antibiotics, steroids, and anti-TNF therapy, who achieved endoscopic remission and subsequent anemia resolution after starting Vedolizumab.

A 20-year-old woman was diagnosed with extensive severe acute UC at the age of 16 . She underwent an ileal pouch-anal anastomosis due to refractoriness to steroids and Infliximab. One year later, a relapsing $\mathrm{CP}$ was diagnosed based on disabling symptoms, elevated inflammatory markers, pouchoscopy, and histologic findings. Initially she was treated with antibiotics (ciprofloxacin plus metronidazole) and oral budesonide with partial clinical response. Complementary study excluded infectious pouchitis, Crohn's disease, vasculitis, ischemia, and autoimmune pouchitis. Simultaneously she was diagnosed with a severe symptomatic AIHA with the lowest hemoglobin level of $5 \mathrm{~g} / \mathrm{dL}$, which required therapy with high doses of steroids. AIHA diagnosis was established according to the increased total bilirubin levels ( 3 times the upper limit of normal) with predominance of unconjugated bilirubin, increased lactate dehydrogenase (2.5 times higher than the normal range), consumption of haptoglobin $(<10 \mathrm{mg} / \mathrm{dL})$, increased reticulocyte count, positive Coombs test (direct and indirect), and increased erythroblasts count with normal myeloid-erythroid ratio 
and no atypia in the bone marrow examination. Under steroids, the clinical picture was an incomplete hematological response and maintenance of recurrent antibiotic refractory severe pouchitis. Adalimumab was started without pouchitis remission and with a transient hematological response allowing steroid tapering. Due to persistence of disabling symptoms and considering the lack of therapeutic options, we decided to introduce Vedolizumab $300 \mathrm{mg}$ parenterally at 0,2 , and 6 weeks and then every 8 weeks. Patient reported symptoms improvement at week 12 and a pouchoscopy revealed only mucosal edema after 6 months of therapy. Her inflammatory markers and hemoglobin normalized on repeat testing, allowing steroid withdrawal.

Vedolizumab is a gut-selective monoclonal antibody that blocks lymphocyte trafficking by interacting with a $4 \beta 7$ heterodimer, which has an established role in UC [4]. Hemolytic anemia is a rare extraintestinal manifestation of UC and there are no cases reported among patients with CP [5]. There have been case reports of pouchitis alone (without AIHA) treated with Vedolizumab [3] and also of UC associated with AIHA [5] but no unique combination of pouchitis and AIHA successfully treated with this drug. Vedolizumab may be an option for anti-TNF refractory pouchitis and may control anemia by achieving luminal disease remission. Data from ongoing and new trials should establish Vedolizumab efficacy and safety in patients with refractory $\mathrm{CP}$, even when associated with extraintestinal manifestations.

\section{Statement of Ethics}

Informed consent was obtained from the patient regarding the manuscript.

\section{Disclosure Statement}

P.M. is a consultant for Abbvie, Ferring, Hospira, Janssen, MSD, Pfizer, Takeda.

\section{Funding Sources}

This work was not funded.

\section{Author Contributions}

D.M. - conception and writing of the manuscript; P.M. - copyediting of the manuscript, manuscript coordination; all the authors critically revised it for important intellectual content and provided final approval of the version to be submitted.
References

Refractory Chronic Pouchitis and Autoimmune Hemolytic Anemia Successfully Treated with Vedolizumab
Peyrin-Biroulet L, Germain A, Patel AS, Lindsay JO: Systematic review: outcomes and post-operative complications following colectomy for ulcerative colitis. Aliment Pharmacol Ther 2016;44:807-816.

-2 Segal JP, Ding NS, Worley G, Mclaughlin S, Preston S, Faiz OD, Clark SK, Hart AL: Systematic review with meta-analysis: the management of chronic refractory pouchitis with an evidence-based treatment algorithm. Aliment Pharmacol Ther 2017;45: 581-592.

3 Philpott J, Ashburn J, Shen B: Efficacy of vedolizumab in patients with antibiotic and an- ti-tumor necrosis alpha refractory pouchitis. Inflamm Bowel Dis 2017;23:E5-E6.

4 Feagan BG, Rutgeerts P, Sands BE, Hanauer S, Colombel, JF, Sandborn WJ: Vedolizumab as induction and maintenance therapy for ulcerative colitis. N Engl J Med 2013;369:699-710.

5 Uzzan M, Galicier L, Gornet J-M, Oksenhendler E, Fieschi C, Allez M, Bouhnik Y, Kirchgesner J, Boutboul D, Treton X, Gérard L, Mahévas M, Cosnes J, Amiot A: Autoimmune cytopenias associated with inflammatory bowel diseases: insights from a multicenter retrospective cohort. Dig Liver Dis 2017;49:397-404. 